Kumawula, Vol. 2, No.3, Desember 2019, Hal 248 - 261 DOI:http://10.24198/kumawula.v1i3.25256

ISSN 2620-844X (online)

Tersedia online di http://jurnal.unpad.ac.id/kumawula/index

\title{
PENGEMBANGAN PEMASARAN BORDIR DAN KELOM GEULIS TASIKMALAYA MELALUI MEDIA SOSIAL
}

\author{
Santi Susanti ${ }^{1}$, Wahyu Gunawan ${ }^{2}$, Sukaesih $^{3}$ \\ ${ }^{1}$ Departemen Komunikasi Massa, Fakultas Ilmu Komunikasi UNPAD \\ ${ }^{2}$ Departemen Sosiologi, Fakultas Ilmu Sosial dan Ilmu Politik UNPAD \\ ${ }^{3}$ Departemen Komunikasi \& Informasi, Fakultas Ilmu Komunikasi UNPAD \\ ${ }^{1}$ santi.susanti@unpad.ac.id, ${ }^{2}$ wahyu.gunawan@unpad.ac.id \\ ${ }^{3}$ sukaesih@unpad.ac.id
}

\begin{abstract}
ABSTRAK
Pengabdian Pada Masyarakat (PPM) ini berjudul "Pelatihan Pengembangan Pemasaran Bordir dan Kelom geulis Tasikmalaya". Kegiatan ini merupakan terintegrasi dengan Riset Fundamental Unpad (RFU) lanjutan tahun 2019. Pemilihan judul PPM kali ini dilatarbelakangi oleh meluasnya pangsa pasar bagi para pelaku ekonomi kreatif seiring berkembangnya penggunaan media sosial dari semula sebagai media komunikasi menjadi media pemasaran produk barang dan jasa. Ini merupakan peluang bagi pelaku usaha bordir dan kelom geulis di Kota Tasikmalaya untuk meluaskan pemasarannya ke skala nasional hingga internasional. Bahkan, bukan tidak mungkin, melebarkan pasarnya hingga skala ekspor. Adanya kegiatan PPM ini diharapkan dapat menumbuhkan semangat pelaku usaha bordir maupun kelom geulis di Kota Tasikmalaya untuk mengoptimalkan penggunaan media sosial sebagai media pemasaran dalam memperluas pasar dan meningkatkan omset yang diperoleh. Kegiatan PPM ini diselenggarakan pada 30 Juli 2019 di Rumah Kreatif BRI di Jalan Siliwangi 51, Kota Tasikmalaya, dengan peserta pelaku usaha bordir dan kelom geulis di Kota Tasikmalaya. Kegiatan ini menghadirkan pembicara dari Kamar Dagang dan Industri (Kadin) Kota Tasikmalaya dan Dosen STMIK DCI, Kota Tasikmalaya. Metode yang digunakan dalam PPM ini metode ceramah dan berbagi pengalaman memasarkan produk melalui jalur online. Metode ini digunakan untuk memotivasi dan menguatkan UKM di Kota Tasikmalaya untuk menggunakan media sosial yang tersedia, sebagai sarana untuk meluaskan pemasaran. Hasil evaluasi terhadap para peserta pelatihan menunjukkan adanya manfaat yang diperoleh peserta dari materi yang disampaikan narasumber, baik yang berkaitan langsung maupun tidak berkaitan langsung dengan media sosial. Walaupun setelah mengikuti pelatihan tersebut, peserta belum mempraktikkan materi yang diberikan, setidaknya pelatihan membuka wawasan peserta mengenai metode pemasaran yang bisa dilakukan selain pemasaran offline yang biasa dilakukan. Para peserta berharap, ke depannya, pelatihan lebih banyak menghadirkan para praktisi, agar materi pelatihan bisa diarahkan pada materi praktis, lebih kekinian, dan waktunya diperpanjang.
\end{abstract}

Kata kunci: pemasaran, media sosial, motivasi, pengetahuan

\section{DEVELOPMENT OF MARKETING FOR EMBROIDERY AND "KELOM GEULIS" TASIKMALAYA THROUGH SOCIAL MEDIA}

\author{
ABSTRACT \\ The title of our Community Service (PPM) activity is "Training on Marketing Development of \\ Embroidery and Kelom geulis Tasikmalaya". This activity is integrated with Riset Fundamental Unpad
}


$(R F U)$ in 2019. The title is motivated by the expanding market share for a creative economic entrepreneur in line with the development of social media usage as a media marketing products and services. This is an opportunity for embroidery and kelom geulis entrepreneurs IN Tasikmalaya City to expand their marketing to a national and international scale. The existence of PPM activities is expected to foster the enthusiasm of embroidery and kelom geulis entrepreneurs in Tasikmalaya City to optimize the use of social media as a marketing medium in expanding markets and increasing turnover obtained. The PPM activity was held on July 30, 2019, at BRI's Creative House on Jalan Siliwangi 51, Tasikmalaya City. The participants are embroidery and kelom geulis entrepreneurs in Tasikmalaya City. We present the speakers from Tasikmalaya City Chamber of Commerce and Industry (Kadin) and STMIK DCI Lecturer, Tasikmalaya City. We use the lecture method and sharing experiences in marketing products through online media to motivate and strengthen SMEs in the City of Tasikmalaya to use available social media to expand the product marketing. The results showed that the presentation material brings benefits for the participants, the benefits are directly or indirectly are related to social media. Even after participating in the training, the participants did not practice the material provided, at least the training opened the participants' insights into marketing methods that could be carried out other than the usual offline marketing. The participants hoped, in the future, the training would bring more practitioners, so that the training materials could be directed to practical, more contemporary, and extended time.

Keywords: marketing, social media, motivation, knowledge

\section{PENDAHULUAN}

Potensi kreatif dan naluri berbisnis orang-orang Tasikmalaya menjadikan kota yang berada di kawasan Priangan Timur tersebut dikenal sebagai pusat kerajinan di Jawa Barat. Beragam jenis kerajinan dihasilkan dari kreatifitas masyarakat Tasikmalaya. Dua diantaranya adalah bordir dan kelom geulis. Kerajinan bordir berkaitan dengan seni merajut benang pada kain membentuk pola hiasan yang indah menggunakan mesin jahit manual maupun mesin bordir otomatis. Sementara kelom geulis merupakan kerajinan alas kaki berbahan dasar kayu yang dihias sedemikian rupa sehingga terlihat geulis (cantik). Sentra kerajinan bordir berada di kawasan Tanjung, Kecamatan Kawalu, sedangkan kerajinan kelom geulis berpusat di Kecamatan Tamansari. Bordir dan kelom geulis telah lama menjadi sumber penghasilan sebagian besar masyarakat Tasikmalaya yang dikenal di dalam negeri dan telah diekspor ke ke berbagai negara, antara lain Malaysia, Brunei, Arab Saudi, Dubai dan Amerika Serikat.

Umumnya, skala pengolahan kerajinan bordir dan kelom adalah home industry dengan tata kelola yang terlembaga secara tradisional. Dalam penelitiannya tentang pengrajin bordir Tasikmalaya, Yus Darusman mengemukakan, tata kelola industri kerajinan Tasikmalaya terlembaga secara tradisional, melalui kelembagaan produksi oleh para pengrajin handal, kelembagaan distribusi oleh para pedagang antarkota dan antardaerah serta kelembagan pemasaran, baik melalui sentra maupun melalui pasar lokal, nasional dan pasar antarpulau bahkan ekspor ke luar negeri. Pola tata niaga tersebut mampu mengangkat perekonomian masyarakat Tasikmalaya dan produk yang dihasilkan tidak kalah menarik dibandingkan produk-produk modern yang dihasilkan oleh mesin. (Darusman, 2016)

Kemampuan pengrajin di Tasikmalaya dalam mempertahankan dan mengembangkan usahanya di tengah persaingan dengan produk yang dihasilkan oleh mesin pabrikan menjadi hal yang menarik untuk diteliti. Di sisi lain, berkembangnya penggunaan media sosial yang semula sebagai media 
komunikasi menjadi media pemasaran produk yang dihasilkan maupun dijualkan oleh warga net, menjadi peluang yang sangat terbuka untuk mengembangkan pemasaran, termasuk oleh pengrajin bordir dan kelom geulis di Kota Tasikmalaya.

Potensi pasar digital di Indonesia sangat besar. berdasarkan jumlah warga Indonesia yang mengakses internet serta cara warga Indonesia mengakses internet. Berdasarkan jumlah pengakses, Indonesia menempati urutan kedua terbanyak pengakses Facebook dengan jumlah 35,4 juta user, melebihi jumlah penduduk Kanada, serta urutan keempat terbesar pengakses Twitter dengan jumlah 4,8 juta user, setara dengan jumlah penduduk Singapura. (Mawardi, 2018)

Berdasarkan cara warga Indonesia mengakses internet, $83 \%$ dari internet cafe, 22\% dari smartphone, dan 16\% dari rumah. (Mawardi, 2018). Dengan demikian, potensi pangsa pasar online sangat terbuka luas dan siapa pun dapat mengaksesnya kapan saja. Kini, siapa pun yang memiliki produk untuk dipasarkan, dapat menjadi wirausahawan online.

Demikian pula dengan pengrajin bordir dan kelom geulis Tasikmalaya. Berdasarkan wawancara dengan beberapa pelaku usaha bordir dan kelom geulis, yang dilakukan pada periode Juni 2018, media sosial telah menjadi bagian dari pemasaran usaha mereka meski dalam praktiknya masih belum optimal, karena terkendala beberapa hal, diantaranya keterbatasan SDM pengelola dalam jumlah dan keterampilan yang dimiliki, serta waktu yang dibutuhkan untuk mengelolanya.

Untuk itulah, kegiatan PPM ini diselenggarakan dengan judul "Pelatihan Pengembangan Pemasaran Bordir dan Kelom geulis Tasikmalaya". Kegiatan PPM ini bertujuan memberikan edukasi mengenai pemanfaatan media sosial dalam memasarkan produk bordir dan kelom geulis Tasikmalaya. Target peserta pelatihan ini adalah pengrajin bordir dan kelom geulis di Kota Tasikmalaya yang belum atau sedang memanfaatkan media sosial sebagai media pemasaran produk kerajinan yang dihasilkan. Target jangka panjang dari kegiatan ini, para pengrajin mau dan mampu mengoptimalkan penggunaan media sosial dalam memasarkan produk mereka sehingga memberikan impact berupa peningkatan income. Dengan peningkatan pendapatan, para pengrajin lebih bergairah lagi dalam memproduksi kerajinan bordir dan kelom geulis.

\section{Pelatihan}

Pelatihan adalah keseluruhan aktivitas yang dirancang untuk meningkatkan kinerja dalam melaksanakan pekerjaan dengan mempertimbangkan berbagai masukan proses, keluaran, dan dampak. Kegiatan tersebut dirancang secara sistematis untuk mencapai tujuan yang diharapkan. Pelatihan merupakan “.....pengalaman-pengalaman instruksional (instructional experiences) yang diberikan oleh pimpinan bagi karyawan. Artinya pelatihan merupakan kegiatan yang dirancang dalam lembaga pelatihan untuk meningkatkan kinerja seseorang dalam bidang pekerjaaan melalui pengembangan pengetahuan, keterampilan dan sikap" (Davis \& Adelaide, 1998: 65).

Pelatihan merupakan proses yang disengaja atau direncanakan, bukan kegiatan yang bersifat kebetulan atau spontan. Pelatihan merupakan proses yang terdiri dari serangkaian kegiatan yang 
sistematis dan terencana yang terarah pada suatu tujuan. Pelatihan diselenggarakan baik terkait kebutuhan dunia kerja maupun dalam lingkungan masyarakat yang lebih luas. (Kamil, 2007: 10)

Tahapan persiapan pelaksanaan rencana program pelatihan meliputi: (1) Memprioritaskan dan menganalisa masalah-masalah hasil identifikasi kebutuhan lebih terinci, (2) Identifikasi alternatif pemecahan masalah yang terbaik, (3) Identifikasi sumber daya yang tersedia (sumber daya alam, manusia serta modal) untuk memecahkan masalah tersebut, (4) Pengembangan rencana kegiatan serta pengorganisasian pelaksanaannya, (5) Menyediakan sumber daya yang dibutuhkan untuk pelaksanaan kegiatan, (6) Pelaksanaan kegiatan sesuai rencana, (7) Pemantauan pelaksanaan dan kemajuan kegiatan dan membuat perbaikan kalau diperlukan.

\section{Pemasaran}

Pemasaran menjadi fokus dalam pelatihan kali ini. Pemasaran menjadi persoalan yang penting dikarenakan, produk bordir manual dan kelom geulis merupakan produk handmade atau buatan tangan yang jumlah produksinya terbatas dan membutuhkan waktu yang agak lama untuk menyelesaikan pesanan dibandingan dengan produk massal yang dibuat dengan bantuan mesin produksi yang terkomputerisasi.

Selama ini, para pengrajin/pelaku usaha bordir dan kelom geulis Tasikmalaya, masih belum optimal memanfaatkan media sosial sebagai sarana promosi produk untuk mengembangkan pemasaran.

Masih terdapat beberapa kendala yang ditemui dari para pelaku usaha. Sebagian besar karena mereka tidak begitu menguasai teknologi perangkat untuk melakukan promosi. Kemudian, sumber daya terbatas untuk pengelolaan media sosialnya, karena sebagian besar pelaku usaha bordir dan kelom geulis sudah "berumur" sehingga mereka hanya memercayakan pada orang-orang yang bisa, misalnya anaknya atau saudara, meski dalam pengelolaannya bisa saja tidak tertangani, karena kesibukan lain.

Pengembangan pemasaran yang dimaksud dalam tulisan ini adalah kemampuan pelaku usaha untuk dapat melebarkan pemasaran produknya tidak hanya dipasarkan secara offline di galeri maupun di pameran, juga secara online. Pemanfaatan media sosial menjadi penting, agar upaya pemasaran produk dapat mencapai sasaran dan mendapatkan hasil yang sesuai dengan harapan. Untuk itu diperlukan kemampuan manajemen pemasaran serta melakukan bauran promosi atau marketing mix.

Menurut Kotler dan Amstrong (2016: 51) bauran pemasaran (marketing mix) adalah seperangkat alat pemasaran taktis yang dipadukan perusahaan untuk menghasilkan respons yang diinginkan di pasar sasaran. Sedangkan Buchari Alma mendefiniskan bauran pemasaran sebagai suatu strategi mencampuri kegiatan-kegiatan pemasaran, agar dicari kombinasi maksimal sehingga mendatangkan hasil yang memuaskan (Alma, 2016). Marketing mix terdiri atas empat komponen atau disebut 4P yaitu product, price, place dan promotion. Dalam pemasaran jasa, terdapat beberapa alat pemasaran tambahan seperti people (orang), physical evidence (fasilitas fisik) dan process (proses) sehingga dikenal 7P maka dapat disimpulkan bauran pemasaran jasa yaitu product, price, place, promotion, people, physical evidence, process. (Kotler \& Amstrong, 2016) 


\section{Media Sosial}

Media sosial adalah sebuah media online. Kehadirannya yang berbasis internet menunjukkan telah terjadi pergeseran arah penggunaan media komunikasi, yang semula bersifat klasik (media elektronik dan cetak) menjadi media baru (new media) berbasis internet yang menjadi saluran akses dalam berbagai bidang, yaitu pendidikan, budaya, sosial, ekonomi, hukum, juga politik.

Andreas Kaplan dan Michael Haenlein mendefinisikan media sosial sebagai "Suatu kelompok aplikasi berbasis internet yang dibangun di atas dasar ideologi dan teknologi Web 2.0, dan yang memungkinkan penciptaan dan pertukaran user-generated content" (Kaplan \& Haenlein, 2010). Media sosial dikenal juga sebagai situs jejaring sosial, yang mengizinkan user untuk dapat terhubung dengan cara membuat informasi pribadi sehingga dapat terhubung dengan orang lain. Informasi pribadi itu bisa berupa foto atau tulisan.

Media sosial memudahkan para penggunanya berpartisipasi, berbagi dan menciptakan isi informasi dalam blog, jejaring sosial, wiki, forum dan dunia virtual lainnya. Blog, jejaring sosial dan wiki mungkin merupakan bentuk media sosial yang paling umum digunakan oleh masyarakat di seluruh dunia (Ardianto, 2011: 165).

Dalam media sosial, setiap orang bisa membuat web page pribadi, kemudian terhubung dengan teman-teman untuk berbagi informasi dan berkomunikasi. Jika media konvensional menggunakan media cetak dan media broadcast, maka media sosial menggunakan internet. Saat teknologi internet dan mobile phone makin maju, maka media sosial pun ikut tumbuh pesat. Kini, untuk mengakses Facebook atau Twitter misalnya, bisa dilakukan di mana saja dan kapan saja hanya dengan melalui telepon selular. Demikian cepatnya orang dapat mengakses media sosial, mengakibatkan terjadinya fenomena besar terhadap arus informasi, tidak hanya di negara-negara maju, juga di negara berkembang seperti di Indonesia. Media sosial atau social networking (jejaring sosial) yang umum diketahui dan digunakan antara lain Blog, Facebook, Twitter, Instagram, WhatsApp, Youtube, Google Plus, Path dan sebagainya. Jika media tradisional menggunakan media cetak dan media broadcast, maka media sosial menggunakan internet. Dengan demikian, media sosial sebagai sarana komunikasi memiliki peran membawa orang (penggunanya) untuk berpartisipasi secara aktif dengan memberi kontribusi dan feedback secara terbuka, baik untuk membagi informasi maupun memberi respon secara online dalam waktu yang cepat.

Berdasarkan data laporan We Are Social yang dikutip dari https://tekno.kompas.com, hingga Januari 2019, jumlah pengguna media sosial di Indonesia mencapai 150 juta pengguna atau 56 persen dari jumlah penduduk di Indonesia. Jumlah pengguna media sosial di Indonesia, meningkat 20 juta dari tahun lalu. Sebagian besar penggunanya adalah generasi milenial dengan rentang usia 18 hingga 34 tahun. 


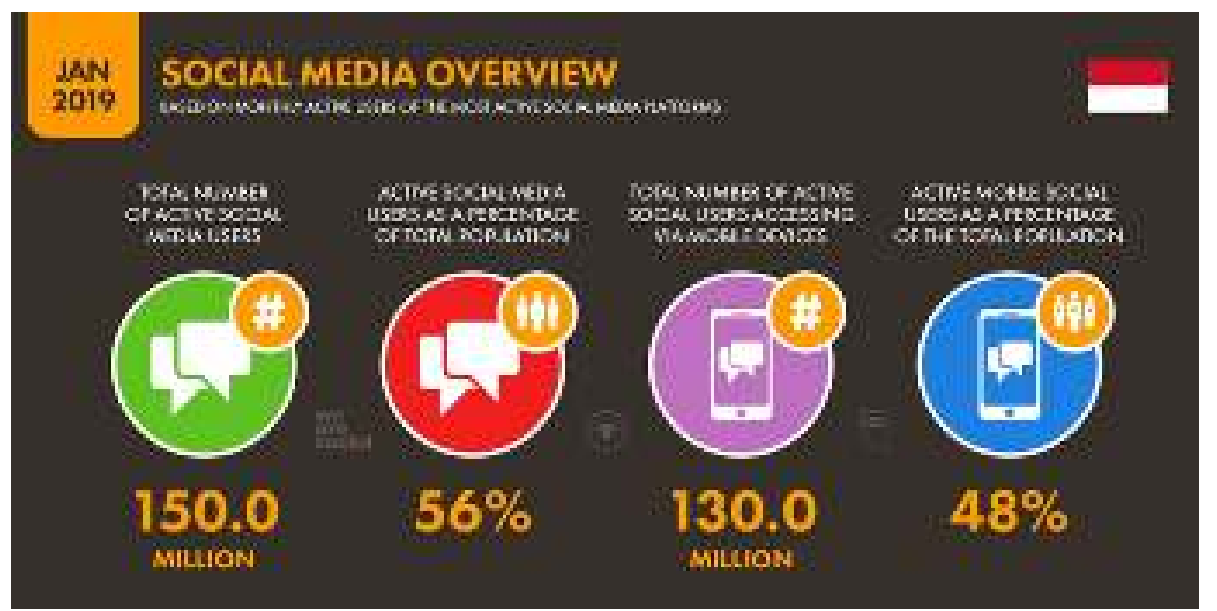

Gambar 1. Jumlah pengguna internet dan media sosial di Indonesia per Januari 2019

(Sumber: tekno.kompas.com)

Berdasarkan gambar tersebut, dapat diketahui bahwa perangkat mobile seperti smartphone dan tablet masih menjadi perangkat favorit yang digunakan 130 juta pengguna media sosial aktif Indonesia, atau $48 \%$ dari total populasi Indonesia yang berjumlah sekira 268 juta orang. Hampir seluruh pengguna media sosial di Indonesia menggunakan aplikasi pesan instan seperti WhatsApp atau Line. Penetrasi pengunaan aplikasi pesan instan sebesar 100 persen, sementara aplikasi media sosial kontribusi engagement-nya mencapai 92 persen. Sementara itu, orang-orang Indonesia banyak menghabiskan waktu 3 jam 26 menit untuk menggunakan media sosial dengan segala tujuan. Rata-rata, satu pengguna internet di Indonesia memiliki setidaknya 11 akun berbagai media sosial. Platform media sosial yang paling digandrungi oleh orang Indonesia, di antaranya YouTube, Facebook, WhatsApp, Line 33\%. (Pertiwi, 2019)

Angka ini menjadi cerminan bahwa peluang pasar online terbuka sangat luas. Penggunanya seolah tidak pernah habis, malahan kian bertambah dari hari ke hari. Oleh karena itu, pemanfaatan media sosial sebagai media pemasaran pentig adanya dalam rangka peningkatan pesar oleh pelaku usaha bordir dan kelom geulis.

Data tersebut menunjukkan betapa besarnya potensi media sosial untuk dimanfaatkan dalam memasarkan produk bordir dan kelom geulis yang dihasilkan para perajin di Tasikmalaya. Potensi tersebut akan bermanfaat secara nyata, jika diberdayakan dengan baik. Untuk itu, pengetahuan mengenai penggunaan media sosial dalam menunjang pemasaran dan penjualan produk bordir dan kelom geulis Tasikmalaya mutlak diperlukan, dan yang paling utama, kemauan dalam pemanfaatannya memegang peranan penting dalam kesuksesan pemanfaatan media sosial dalam penjualan produk bordir dan kelom geulis Tasikmalaya.

Melihat peluang tersebut, maka pelatihan ini diadakan. Para peserta pelatihan PPM Unpad ini adalah pelaku usaha bordir dan kelom geulis Kota Tasikmalaya yang sudah maupun belum menggunakan media sosial sebagai saluran pemasaran produknya. Para pelaku usaha bordir dan kelom 
geulis diundang menghadiri pelatihan dalam rangka menambah wawasan mengenai pemasaran produk melalui media sosial. Pelatihan ini diharapkan dapat membantu meningkatkan keterampilan pelaku usaha bordir dan kelom geulis dalam menggunakan media sosial sebagai media penjualan produk sehingga dapat membantu meningkatkan pendapatan mereka.

\section{METODE}

Menurut Muhibbin Syah, metode pengajaran dapat berbentuk ceramah, demonstrasi, diskusi serta praktik yang bertujuan untuk memberikan pemahaman pengetahuan, pemahaman aplikasi, dan pemahaman analisis, sintesis, serta evaluasi. (Syah, 1995)

Pengabdian Pada Masyarakat (PPM) ini dilaksanakan pada 30 Juli 2019 di Rumah Kreatif BUMN BRI, Jalan Siliwangi No. 51, Kota Tasikmalaya, mulai jam 8 pagi. Peserta kegiatan ini adalah 20 pelaku usaha bordir dan 20 pelaku usaha kelom geulis di Kota Tasikmalaya yang diundang mengikuti kegiatan. Kegiatan PPM ini menghadirkan pemateri dari Kadin Kota Tasikmalaya, Ibu Santi Nining Susanti dan Ketua STMIK DCI Kota Tasikmalaya, Ibu Aneu Yulianeu, S.T., S.E., M.M.

Kegiatan dilaksanakan dengan metode ceramah dan berbagi pengalaman memasarkan produk melalui jalur online. Di setiap akhir sesi ceramah, peserta diberi kesempatan untuk bertanya kepada pemateri.

\section{HASIL DAN PEMBAHASAN}

\section{Pelaksanaan PPM}

Kegiatan Pengabdian Pada Masyarakat (PPM) ini diawali dengan registrasi peserta yang terdiri dari pelaku usaha bordir dan kelom geulis, masing-masing 20 orang. Juga perwakilan dari Dinas KUMKM Perindag Kota Tasikmalaya, serta narasumber yang akan memberikan materi kepada para peserta pelatihan.

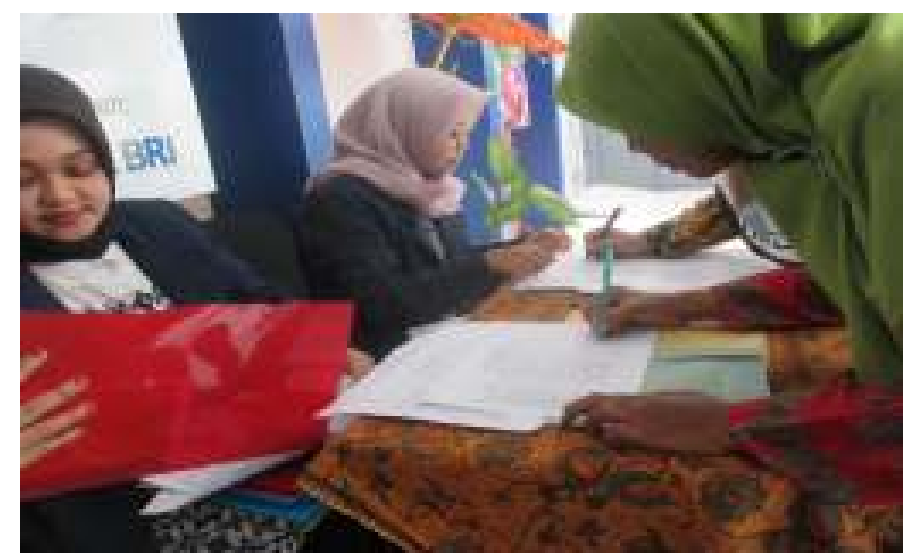

Gambar 2. Registrasi peserta pelatihan

Setelah peserta berkumpul, acara awali dibuka oleh Bapak Taufik Hermansyah, Wakil Pimpinan Rumah Kreatif BRI, yang menjadi lokasi berlangsungnya acara. 


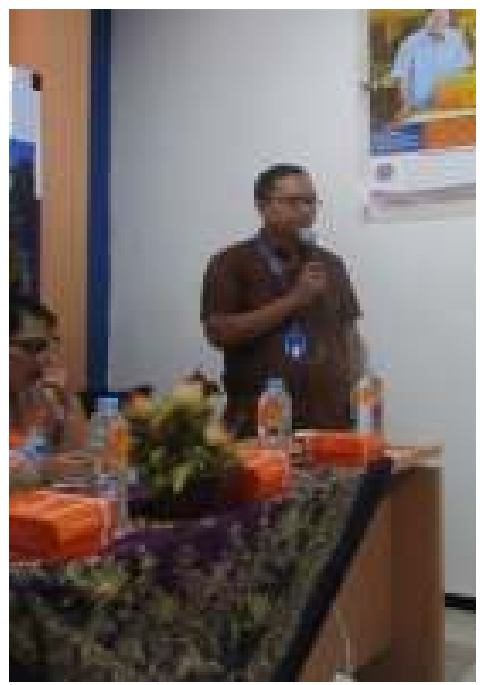

Gambar 3. Bapak Taufik Hermansyah dari RKB BRI Tasikmalaya memberikan sambutan sekaligus membuka acara PPM 2019

Materi pertama mengenai pemasaran disampaikan oleh Ibu Santi Nining Susanti, staf ahli Kadin Kota Tasikmalaya dalam pengembangan ekonomi daerah. Dalam materinya, Bu Santi mengajak peserta pelatihan untuk memahami karakter pasar lokal, nasional dan internasional untuk produk bordir dan kelom Tasikmalaya.

$\mathrm{Bu}$ Santi menekankan, ke pangsa pasar manapun, yang perlu diperhatikan adalah seberapa besar porsi pasar; target pasar; karakter pasar yang dituju; pengembangan produk; kebijakan terhadap pelangga, serta Unique Selling Point atau keunikan daya jual yang ditawarkan, yang berbeda dengan para pesaing.

Pergeseran pola kebiasan konsumen ke platform digital marketing merupakan peluang yang bisa ditangkap oleh pelaku usaha. Kemampuan beradaptasi dengan teknologi menjadi suatu keharusan jika ingin terlibat dalam pemasaran pangsa pasar digital.

Intinya, untuk dapat bertahan di era digital ini, yang harus selalu dikembangkan dan dilaksanakan oleh pelaku usaha bordir dan kelom adalah dengan selalu kreatif untuk berinovasi, melakukan promosi, membentuk citra melalui branding, menciptakan pasar sendiri, serta menekankan kerjasama daripada kompetisi. 


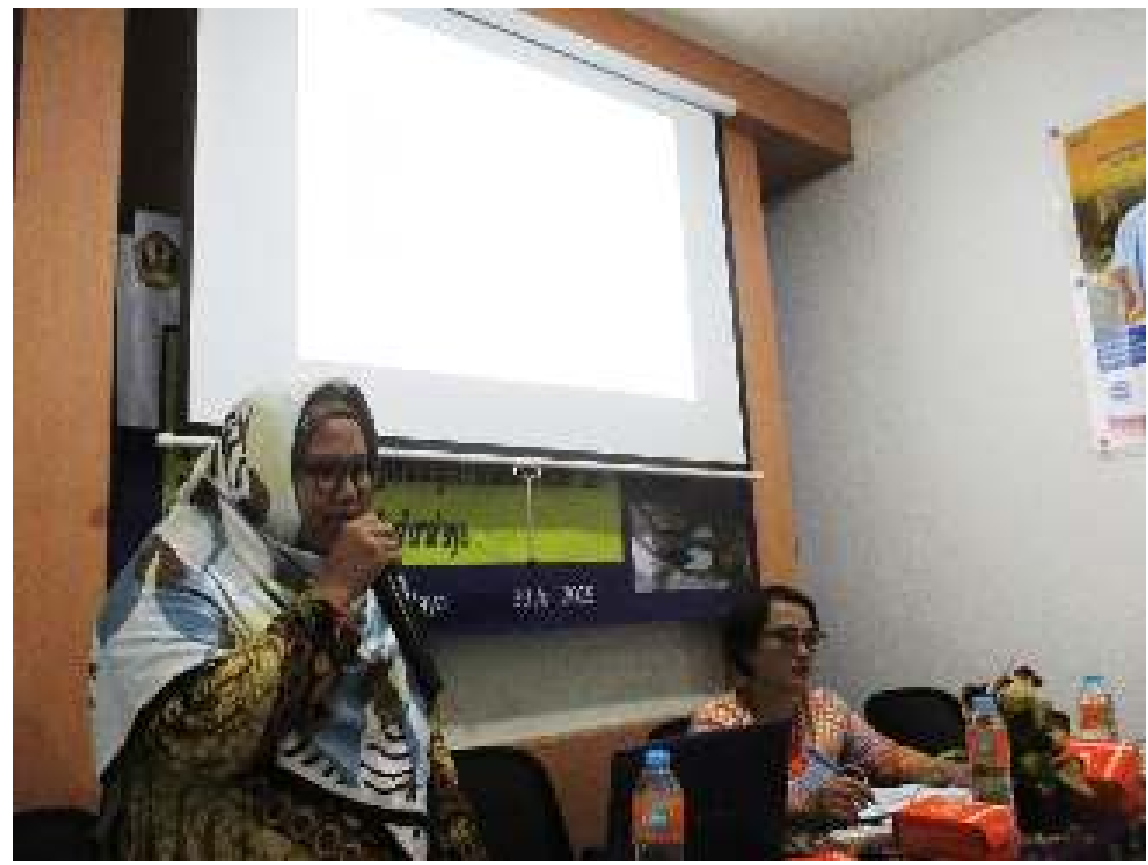

Gambar 4. Bu Santi Nining dari Kadin, menyampaikan materi pelatihan berupa memahami karakter pasar untuk bordir dan kelom

Materi kedua disampaikan oleh Ibu Aneu Yulianeu, dosen dan Ketua STMIK DCI, yang menekankan pentingnya pemasaran lewat media digital pada era digital saat ini. Pemasaran melalui media digital memiliki beberapa keunggulan, yaitu: Pasar lebih luas jangkauannya, biaya yang dikeluarkan tidak sebanyak usaha offline, promosi bisa memanfaatkan media sosial yang ada, efektifitas pemasaran dapat diukur secara real time, hitung-hitungan balik modalnya bisa diperkirakan.

Aneu juga telah menyampaikan apa saja yang perlu dilakukan supaya bisa melakukan pemasaran online dengan baik. Pemasaran bisa dilakukan sendiri pengelolaannya atau memanfaatkan platform media sosial serta market place yang ada. Cara yang bisa dilakukan untuk pemasaran digital antara lain social media marketing, online advertising melalui website, email marketing dan video maketing melalui youtube.

Intinya, untuk menekuni pemasaran digital, jangan malas untuk selalu belajar update teknologi atau informasi yang dibutuhkan. Harus melek teknologi. Perubahan dimulai dari diri sendiri. Tidak ada yang bisa mengubah diri kita selain diri kita sendiri. 


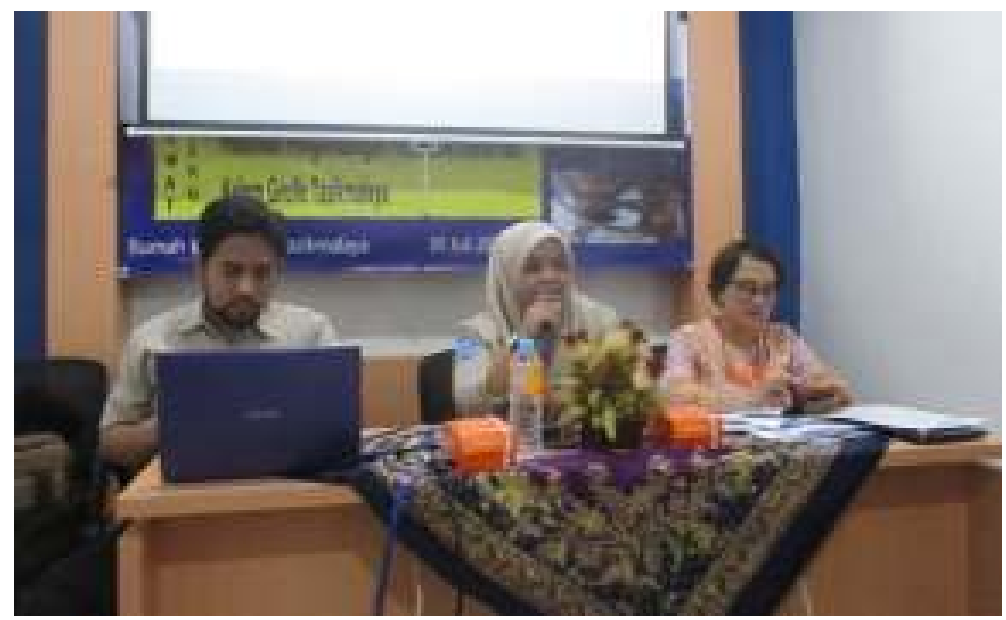

Gambar 5. Bu Aneu Yulianeu, Dosen STMIK DCI menyampaikan materi kepada peserta pelatihan PPM

Aneu menyarankan, para perajin bordir dan kelom menjadikan media digital sebagai bonus dari profit yang biasa diperoleh melalui penjualan online sehingga tidak berarti meninggalkan yang offline.

Ketika membuat produk, sesuaikan dengan selera pasar, bukan dengan selera kita. Syarat utama digital marketing adalah membuat website. Adapun materi yang diberikan kepada peserta pelatihan adalah “Online Marketing”.

Aneu mengingatkan adanya beberapa hal yang perlu diperhatikan dalam memasarkan produk secara mobile, yakni 5 P, Promotion (promosi), Price (harga), Place (tempat), Product (produk), Packaging (kemasan).

Setelah menyampaikan materi, para peserta diberi kesempatan untuk bertanya kepada pemateri. Para peserta pun tidak melewatkan kesempatan tersebut untuk bertanya kepada dua narasumber. Dialog interaktif pun terjadi antara peserta dengan pemateri.

Setelah berlangsung dari jam 8 pagi sampai jam 2 siang, kegiatan PPM pun berakhir. Peserta pulang dengan membawa pengetahuan baru tentang pemasaran produknya melalui media sosial.

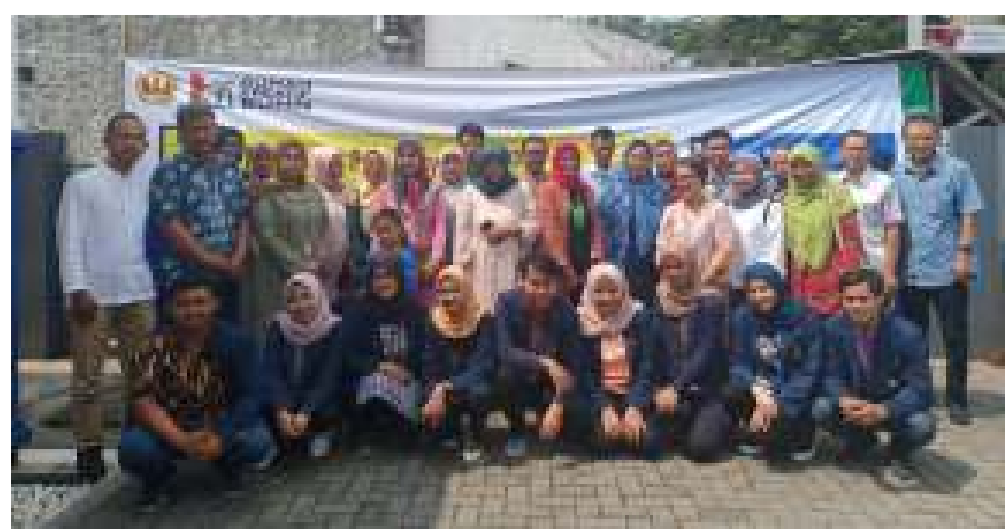

Gambar 6. Foto bersama peserta pelatihan dengan Tim PPM Fikom Unpad 


\section{Evaluasi Kegiatan}

Guna mengetahui efektifitas pelatihan yang diselenggarakan, tim PPM melakukan verifikasi kepada sejumlah pemilik usaha bordir dan kelom geulis dengan mendatangi lokasi usaha maupun rumahnya pasca pelaksanaan PPM. Beberapa pemilik usaha yang dimintai tanggapannya mengenai pelaksanaan PPM yang lalu adalah Astari Aulia (24 thn) dari Mia Bordir.

Menurut Astari, materi yang paling diingatnya di acara tersebut adalah mengenai penentuan pasar ekspor yang harus menyesuaikan diri dengan permintaan negara yang dituju dari warna, motif, dan lainnya. Pangsa pasar sekarang memang tidak bisa lepas dari media sosial, karena siapapun bisa menggunakannya.

Sementara untuk pelatihan PPM, Astari mengusulkan adanya pelatihan yang bersifat teknik sehingga pada pengrajin yang belum begitu paham teknologi bisa ikut mempraktekkan untuk membuat akun media sosial atau akun market place. "Harapan ke depan untuk pelatihan kepada pengrajin. Kalau menurut saya sih lebih langsung ke praktek. Kalau untuk ibu-ibu kan masih banyak yang belum bisa tuh pake gadget jaman sekarang, jadi langsung praktek gimana bikin akun shopee bareng-bareng. Gimana cara masukkin produk kita di akun itu, gimana cara jualan. Kalau menurut saya sih lebih ke situ.”

Mia bordir sendiri memiliki beberapa akun market place. Namun, hingga saat ini belum ada yang pernah beli melalui market place. Faktor penyebabnya, menurut Astari adalah dari harga, yang lebih mahal dari rata-rata harga busana di market place. Selain itu, jangka waktu untuk menyediakan produk. foto produk yang dicantumkan di market place bukanlah barang yang tersedia, melainkan harus dipesan terlebih dahulu dalam waktu dua minggu.

"Nah, itu tuh kalau menurut konsumen, lama. Males nunggunya. Biasanya kan kalau orang-orang yang beli di market place, besoknya langsung datang. Tapi, karena produk kami memang tidak bisa ready. Dan itu membutuhkan waktu cukup lama untuk ready. Kalau cuma satu yang ready, tidak menarik, gitu. Bagusnya kan kalau ready banyak, jadi orang bisa milih.

Menurut Astari, Mia Bordir memiliki akun di Bukalapak, Shopee dan Tokopedia. Namun belum ada satu pun pembeli dari ketiga akun tersebut. Astari pun mengakui tidak begitu tertarik memasarkan produknya melalui market place, dengan beberapa alasan tadi. Akan tetapi, ia lebih sedang berjualan secara offline. Hal tersebut dilatarbelakangi oleh wujud produk yang dipasarkanya, yang lebih memuaskan calon konsumenya jika dilihat dan dicoba langsung ukurannya. 
"Kalau online kan ngawang-ngawang aja. Kalau orang yang belum biasa lihat bordir, ini bordir gimana sih, apa bedanya sama computer. Mereka pasti tidak bisa melihat itu. Kalau offline, mereka akan menilik-nilik dan bisa ngebedain sama komputer. Orang lebih pengen beli kalau offline. Enak jualan langsung kalau menurut pengalaman saya. “

Eming Muhaimin dari Karima Key Kelom geulis, mengatakan, kegiatan pelatihan yang dilangsungkan di RKB secara pribadi menambah wawasan ilmu, yang berharap dapat diterapkan dalam perjalanan bisnisnya.

"Pami mangpaat mah aya secara pribadi nambah wawasan elmu. Anu teu acan terang tadina jadi nambihan. Anu terang, langkung kaemutan. Mudah-mudahan tiasa diterapkeun dina perjalanan bisnis abdi."

(Kalau manfaat buat pribadi menambah wawasan ilmu. Dari yang tadinya belum tau jadi tambah tau. Kalau sudah tau, jadi diingatkan. Mudah-mudahan bisa diterapkan pada perjalanan bisnis saya)

Eming berharap, ke depannya ada pelatihan jangka panjang dengan materi yang lebih praktis, agar bisa dimanfaatkan. Penjualan melalui market place, menurut Eming kurang begitu bagus dibandingkan menjual langsung. Ia berharap dapat dipertemukan dengan buyer. Baginya, hal tersebut lebih efektif.

Mario dari Klarisa Bordir menuturkan, PPM di Rumah Kreatif BRI, memberinya pengetahuan baru, yang membuatnya belajar sehingga memberinya wawasan baru mengenai pemasaran produk bordir melalui media digital. Waktunya mepet sehingga kurang bisa tergali lagi. Mario berharap, jika ada pelatihan seperti di RKB kemarin, lebih digali lagi mengenai desain produk . "Materinya memang dibutuhkan, tapi kalau bisa lebih dieksplor lagi. Fokus ke bordir, Lebih ke desain. Untuk anak muda seperti apa, dewasa seperti apa. “

Iman Ramdhani dari Ariesta Bordir menyarankan waktu pelaksanaan kegiatan diperpanjang hingga 2,5 jam, agar lebih banyak materi yang bisa disampaikan. Selain itu, Iman mengharapkan adanya pelatihan secara praktis, terutama mengenai digital marketing dan materinya lebih menasional.

Berdasarkan pendapat para peserta pelatihan tersebut, dapat dikatakan bahwa pelatihan media sosial yang diselenggarakan oleh tim dosen PPM dari Unpad, yang bekerjasama dengan Dinas KUMKM Perindag Kota Tasikmalaya, memberikan masukan kepada para peserta dalam pemasaran produk menggunakan teknologi. Meski pada praktiknya tidak semua peserta mengimplementasikan pengetahuannya secara nyata, akan tetapi, paling tidak ada informasi yang telah diberikan diketahui oleh peserta sehingga diharapkan dalam waktu mendatang, informasi tersebut menjadi landasan untuk mempraktikkan penggunaan media 
sosial sebagai saluran promosi dan komunikasi produk dengan pembeli yang sudah established maupun dengan calon pembeli dan reseller.

\section{SIMPULAN}

Penggunaan media sosial sebagai sarana pemasaran produk dan komunikasi secara online, saat ini sudah tidak bisa dipisahkan. Penjualan secara langsung melalui transaksi tatap muka untuk pengusaha bordir dan kelom geulis tak bisa diandalkan sepenuhnya. Karena pemasaran secara online akan terus berkembang. Setiap saat akan muncul para pengusaha baru. Jika tidak segera disikapi maka dikhawatirkan turut berpengaruh pada penjualan bordir dan kelom geulis secara keseluruhan.

Pelatihan media sosial dalam rangka pengembangan pasar pengrajin bordir dan kelom geulis Tasikmalaya dirasakan bermanfaat oleh para peserta pelatihan baik secara langsung dalam peningkatan perilaku pemasaran melalui media sosial, maupun tidak langsung berupa terjalinnya kerjasama dengan instansi pemerintah dalam rangka promosi budaya dan promosi produk kerajinan khas Kota Tasikmalaya. Bahkan yang paling sederhana sekalipun adalah sekadar tahu informasinya.

Rencana ke depan, jika masih memungkinkan, perlu diadakan pelatihan yang lebih berorientasi praktis, dengan lebih banyak menghadirkan narasumber praktisi yang dapat berbagi pengalaman juga tips dan trik sukses berbisnis secara online, terutama bagi pelaku usaha bordir dan kelom geulis di Tasikmalaya.

\section{UCAPAN TERIMAKASIH}

Terima kasih kepada Kantor Kesbangpol Kota Tasikmalaya, yang telah mengijinkan dilaksanakannya PPM ini; Pimpinan dan staf Rumah Kreatif BUMN (RKB) BRI yang telah membantu pelaksanaan PPM ini dengan menyediakan tempat dan membuka acara; Narasumber PPM, Ibu Santi Nining Susanti (Kadin Kota Tasikmalaya) dan Ibu Aneu Yulianeu (Ketua STMIK DCI Tasikmalaya) serta para pelaku usaha bordir dan kelom geulis yang berpartisipasi dalam acara PPM ini.

\section{DAFTAR PUSTAKA}

Alma, B. (2016). Manajemen Pemasaran dan Pemasaran Jasa. Bandung: Alfabeta.

Ardianto, E. (2011). Handbook of Public Relations. Bandung: Simbiosa Rekatama Media.

Darusman, Y. (2016). Kearifan Lokal Kerajinan Bordir Tasikmalaya Sebagai Ekonomi Kreatif Terbuka untuk Modern. Journal of Nonformal Education, 2(2). 
Davis, J. R., \& Adelaide, B. (1998). Effective Training Strategies. San Fransisco: Barret-Kochler Publishing, Inc.

Kamil, M. (2007). Model Pendidikan dan Pelatihan (Konsep dan Aplikasi). Bandung: Alfabeta.

Kaplan, A., \& Haenlein, M. (2010). Users of the World, Unite! The Challenges and Opportunities of Social Media. Business Horizons, 53(1), 61.

Kotler, P., \& Amstrong, G. . (2016). Prinsip-prinsip Pemasaran. (13th ed.). Jakarta: Erlangga.

Pertiwi, W. K. (2019). Separuh Penduduk Indonesia Sudah “Melek” Media Sosial. Retrieved December 10, 2019, from https://tekno.kompas.com/read/2019/02/04/19140037/separuh-pendudukindonesia-sudah-melek-media-sosial

Syah, M. (1995). Psikologi Pendidikan, Suatu Pendekatan Baru. Bandung: Remaja Rosdakarya. 